Relations industrielles

Industrial Relations

\title{
Sayer, Jacques, Fonction formation
}

\section{Roch Laflamme}

Volume 54, numéro 3, 1999

URI : https://id.erudit.org/iderudit/051263ar

DOI : https://doi.org/10.7202/051263ar

Aller au sommaire du numéro

\section{Éditeur(s)}

Département des relations industrielles de l'Université Laval

\section{ISSN}

0034-379X (imprimé)

1703-8138 (numérique)

Découvrir la revue

Citer ce compte rendu

Laflamme, R. (1999). Compte rendu de [Sayer, Jacques, Fonction formation]. Relations industrielles / Industrial Relations, 54(3), 626-626.

https://doi.org/10.7202/051263ar

Tous droits réservés (C) Département des relations industrielles de l'Université Laval, 1999
Ce document est protégé par la loi sur le droit d'auteur. L'utilisation des services d'Érudit (y compris la reproduction) est assujettie à sa politique d'utilisation que vous pouvez consulter en ligne.

https://apropos.erudit.org/fr/usagers/politique-dutilisation/ 
overview of policy issues that should be examined in light of future reform initiatives. Perhaps the most interesting policy issue, raised repeatedly by contributors to this section, has to do with proposed restructuring of disability benefit programs to provide work incentives.

In conclusion, while the book is easily accessible to those without quantitative skills, it's subject matter is likely to be of particularly interest to a more limited audience, namely actors in the disability community. Furthermore, because the volume targets an American audience, those less familiar with U.S. social security system may wish to obtain background information before reading the text. The major strength of the book is its reliance on multiple data sources; quantitative analyses which are limited by the available data are supplemented with qualitative evidence to provide a more balanced overview of disability program growth trends. Comments provided at the end of chapters in the first and second sections offer useful and alternative insights to the material presented in those chapters. A weakness of the text is its failure to provide a comprehensive policy proposal that addresses issues of program growth; the third section of the book only hints at such reform initiatives in a disparate fashion.

SILVANA POZZEBON École des Hautes Études Commerciales, Montréal

\section{Fonction formation}

par Jacques SAYER, Paris : Éditions d'Organisation, 1998, 371 p., ISBN 2-70812153-7.

J'ai lu avec grand intérêt ce volume abordant la formation sous l'angle du praticien. Celui-ci- regroupe onze chapitres et fait un survol intéressant des aspects structurels, organisationnels, stratégiques, techniques et humains de la formation en entreprise. L'auteur touche la structure, la politique, la mobilisation, l'intégration, le diagnostic, le plan, la réalisation et l'évaluation de la formation. Il ajoute un chapitre sur les normes ISO 9001,9002 ou 9003.

Dans l'ensemble, la structure du livre est cohérente. Cependant, on n'aborde pas le processus d'apprentissage chez l'humain. De plus, le chapitre 8, "Comment analyser une demande et monter une formation efficace? " devrait se situer avant le chapitre 5 « Comment recenser les besoins de formation? ». L'analyse et la compréhension d'une demande de formation doit, selon moi, se réaliser dès le début du processus. Je m'interroge sur la pertinence du chapitre 11 sur la norme ISO, je n'ai pas bien senti le lien de ce chapitre avec le reste du volume. Si on voulait tirer un fil conducteur entre la formation et les exigences de la norme ISO, on devrait le faire avec plus d'insistance car ce chapitre est un peu succinct.

Finalement, au niveau académique, le fait de n'avoir aucune bibliographie laisse croire que ce livre est la vision ou l'opinion d'une seule personne, ce qui ne semble pas le cas à sa lecture. C'est donc un très bon livre pour les praticiens qui veulent se sensibiliser au processus de la formation en entreprise.

ROCH LAFLAMME Université Laval 